\title{
Üst gastointestinal sistemde mezenkimal tümör düşünülen olgularda endosonografik ince iğne aspirasyon biyopsi sonuçları
}

\author{
Endoscopic ultrasound-guided fine-needle aspiration results in upper gastrointestinal system \\ mesenchymal tumors
}

Ahmet AYDIN ${ }^{1}$, Nevin ORUC ${ }^{1}$, Deniz NART ${ }^{2}$, Ali VERAL ${ }^{2}$

Ege Üniversitesi Tip Fakültesi, ${ }^{1}$ Gastroenteroloji Bilim Dall, ${ }^{2}$ Patoloji Anabilim Dall, Izmir

Giriş ve Amaç: Gastrointestinal mezenkimal tümörler belirgin endoskopik ve endosonografik özelliklere sahip olmalarına karşın histopatolojik tanıda endoskopik biyopsinin başarısı düşüktür. Endosonografik ince iğne aspirasyon biyopsisi lezyonlardan daha derin örnekleme olanağı sağlayan bir yöntemdir. Bu çalışmada retrospektif olarak üst gastrointestinal sistem mezenkimal tümörü düsünülen ve endosonografik ince iğne aspirasyon biyopsisi uygulanan olguların sonuçlarn irdelenmiştir. Gereç ve Yöntem: Çalışmaya 2009-2010 yıllarında kliniğimize başvuran ve üst gastrointestinal sistem mezenkimal tümor şüphesi ile endosonografik ince iğne aspirasyon biyopsisi uygulanan 27 vaka dahil edilmiștir. Olgularda tanımlanan lezyonlardan alınan endosonografik ince iğne aspirasyon biyopsisi materyalleri sitopatolojik incelemeye gönderilmiştir. Materyaller iki ayrı patolog tarafindan değerlendirilerek materyalin yeterliliği ve tanı bildirilmiştir. Bulgular: Çalışmaya yas ortalaması $52.6 \pm 12.1$ yıl (30-84 yas aralığında) olan 18 erkek, 9 kadın dahil edilmiştir. Lezyonların 14'ü özofagus, 13'ü midede yer almaktadır ve

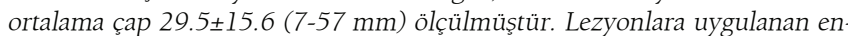
dosonografik ince iğne aspirasyon biyopsisi sonucu elde edilen materyalin sitopatolojik incelemesinde 14 adedinde (\%51.8) iğsi hücreler görülmüştür. Bunlardan 2 olguda malign davranışlı gastrointestinal stromal tümör tanısına ulaşılmış, 4 olguda mezenkimal tümor açısından kuşkulu sitoloji bildirilmiş, kalan 8 olguda iğsi hücre toplulukları görülmüștür. Dokuz olguda hazırlanan hücre bloklarina immünohistokimyasal olarak CD117 boyası uygulanmıștır. Malign gastrointestinal stromal tümör tanısına ulașlan olgularda midede mezenkimal kitle ve perigastrik lenf nodu metastazı saptanarak her iki lezyona endosonografik ince iğne aspirasyon biyopsisi uygulanmıștır. Üç olguya ikinci kez biyopsi uygulanmış ve iki olguda iğsi hücreler görülmüştür. Bu olgularla birlikte tanı oranı \%59.25'e ulaşmıștır. Sonuç: Gastrointestinal mezenkimal tümörlerde endosonografik ince iğne aspirasyon biyopsisi, tanıyı \%51.8 olguda destekler bulgular vermiş, iki olguda malign gastrointestinal stromal tümör tanısına ulaşılmıştır. Tekrarlayan endosonografik ince iğne aspirasyon biyopsisi ile tanı oranı \%59.25'e ulaşmıștır. Sonuç olarak üst gastrointestinal mezenkimal tümörlerde endosonografik inceleme oldukça yararlı iken endosonografik ince iğne aspirasyon biyopsisi tanıya yeterli katkı sağlamamaktadır.

Anahtar kelimeler: Gastrointestinal mezenkimal tümör, endosonografi, ince iğne aspirasyon biyopsisi

\section{GİRIŞ}

Üst gastrointestinal sistem (GIS) subepitelyal lezyonlar genelde endoskopik incelemeler sırasinda tesadüfen saptanır. Subepitelyal lezyonların değerlendirilmesi ve sinıflandırılması için ek görüntüleme yöntemlerine başvurulur (1). Endoskopik ultrason (EUS) subepitelyal patolojilerin incelenmesinde
Background and Aims: Gastrointestinal mesenchymal tumors have characteristic endoscopic and endosonographic imaging findings, whereas endoscopic biopsies are usually not helpful for diagnosis. Endosonography-guided fine-needle aspiration biopsy might allow the procurement of samples from the lesion. We report retrospective results and efficiency of endosonography-guided fine-needle aspiration in upper gastrointestinal mesenchymal tumors. Materials and Methods: Patients admitted to our endosonography unit with pre-diagnosis of upper gastrointestinal system mesenchymal tumors between 2009 and 2010 were evaluated. Patients who underwent endosonography-guided fine-needle aspiration $(n=27)$ were included in the study. The cytopathology specimens were evaluated by two blinded pathologists. The final diagnoses were recorded. Results: Eighteen male and $9 \mathrm{fe}-$ male patients with a mean age of 52.6 \pm 12.1 years (30-84 years) were included in the study. Lesions were located in the esophagus in 14 patients and in the stomach in 13 patients. The mean lesion diameter was $29.5 \pm 15.6 \mathrm{~mm}$ $(7-57 \mathrm{~mm})$. Endosonography-guided fine-needle aspiration procedures were performed by two gastroenterologists. Cytopathology specimens were evaluated and the presence of spindle cells was reported in 14 samples (51.8\%). Out of 14 samples, two were reported as malignant gastrointestinal stromal tumors, whereas 4 specimens were reported as suspicious for mesencymal tumors. Immunohistochemistry for CDI17 was applied to nine specimens and two samples were positive. Malign gastrointestinal stromal tumor was reported in two patients. Those two patients also had pathologic lymph node metastasis and endosonography-guided fine-needle aspiration was applied to the lymph nodes as well. Repeated endosonography-guided fine-needle aspiration was applied to three samples and with repeated fine-needle aspiration, the overall diagnostic efficiency of endosonography-guided fine-needle aspiration in upper gastrointestinal mesencymal tumors reached 59.25\%. Conclusion: Endosonography-guided fine-needle aspiration supports the diagnosis of mesencymal tumors in $51.8 \%$ of patients. With repeated endosonography-guided fine-needle aspiration, the diagnostic yield was $59.25 \%$. Although endosonography is very helpful in the diagnosis of mesencymal tumors, endosonography-guided fine-needle aspiration adds less to the definite diagnosis.

Key words: Gastrointestinal mezencymal tumour, endosonography, fine needle aspiration

ve tanısında tercih edilen yöntemdir. EUS lipom, leimyom, leiomyosarkom ve gastrointestinal stromal tümörlerin (GIST) ayrımında yararlı bulunmuştur (2). EUS bulguları lezyonun invazyonunu ve patolojik lenf nodlarını gösterebildiği için malignite açısından yararlı ek bilgiler verebilmektedir $(3,4)$. 
Üst gastrointestinal sistem mezenkimal lezyonlar geniş bir spektruma sahiptir. Submukozal lezyonlar arasinda GIST, leimyom, leimyosarkom, shwannom ve granüler hücreli tümör gibi neoplastik lezyonlar izlenebilmektedir. Submukozal lezyonlardan lipom ve leimyomlar benign seyirli oldukları için takip edilebilirler. GIST'ler malign potensiyele sahip olduğu için cerrahi tedavi önerilmektedir. Cerrahi veya takip kararı verilirken bazen patolojik örnekleme ve doku tanısı istenebilmektedir. Submukozal lezyonlarda endoskopik biyopsiler tanısal olmamaktadır. EUS eşliğinde ince iğne aspirasyon biyopsisi (EUS-FNA) yapilarak submukozal lezyonlardan daha derin biyopsi alınabilmektedir. EUS ile gastrointestinal mezenkimal tümör düşünülen vakalarda EUS-FNA etkinliğini araştıran çalışmalar vardır. Matsui ve ark. submukozal lezyonlarda EUS-FNA uygulamasının farklı submukozal tümörlerin ayırıcı tanısında yararlı olduğunu bildirmiştir (5).

Mezenkimal lezyonların tanısında EUS FNA'nın tanı için yeterli materyal sağlaması ve alınan örneğe immünhistokimyasal inceleme yapılabilmesi beklenmektedir (5). EUS-FNA'nın farklı lezyonların sitopatolojik tanısında 83\% gibi yüksek oranlarda başarı sağlayabildiği bilinmektedir (6). Ancak EUS-FNA histopatolojik tanıda daha düşük oranlarda başarl göstermektedir (6). Üst gastrointestinal sistemde yerleşmiş mezenkimal tümörlerde EUS-FNA uygulaması bu nedenle halen tartışlan bir konudur. Bu çalışmada retrospektif olarak üst gastrointestinal sistem mezenkimal tümörü düşünülen ve EUS-FNA uygulanan olguların sonuçları irdelenmiştir.

\section{GEREC ve YÖNTEM}

Kliniğimizde 2003-2009 yllları arasinda üst gastrointestinal sistem mezenkimal tümör şüphesi ile EUS yapılan olgular EUS kayıt sisteminden retrospektif olarak incelenmiştir. Bu olgulardan EUS-FNA uygulanan ve detaylı patoloji raporlarına ulaşılan 27 olgu çalışmaya dahil edilmiştir. Olguların demografik verileri kaydedilmiştir. Çalışmaya dahil edilen olguların EUS raporları ve görüntüleri yeniden gözden geçirilmiştir. Çalışma retrospektif olarak Helsinki Deklerasyonu Prensipleri'ne uygun şekilde yürütülmüștür.

Bütün endosonografik incelemeler iki gastroenterolog tarafından uygulanmıştır. EUS işlemleri Fujinon marka EG-530UT linear ve EG-530UR2 radial endosonografi cihazları ile yapılmıs ve FNA işlemleri linear EUS cihazı ve MTW marka 19 veya $22 \mathrm{G}$ iğneler ile gerçekleştirilmiştir. Her olgudan işlem öncesi bilgilendirilmiş onam formu alınmıştır. Hastalar 12 saat açlık sonrası bilinçli sedasyon uygulanarak işleme alınmış, işlem öncesinde kanama parametreleri kontrol edilmiştir. Kanama diatezi olan, antiagregan kullanan veya biyopsiyi kabul etmeyen hastalarda sadece EUS işlemi uygulanmış, EUS-FNA işlemi uygulanmamıştır.

EUS incelemesi sirasinda lezyonun gastrointestinal sistemdeki lokalizasyonu, ölçülen tümör çapı, ekstralüminal sınırının düzensiz olup olmadığı, invazyon bulguları, ekojenitesi, anekoik veya hiperekoik alanların ve eşlik eden lenf nodlarının bulunup bulunmadığı ayrı ayrı incelenerek kaydedilmiştir.

Çalışmaya dahil edilen olguların retrospektif olarak patoloji raporları incelenmiş ve materyal yeterliliği, görülen hücre özellikleri, immünohistokimya (IHC) uygulanıp uygulanmadığı ve bildirilen tanı kaydedilmiştir.

İstatistik analizler SPSS 11,0 istatistik proğramı ile chi-kare testi ve non-paremetrik Kruskal Wallis testi kullanılarak yapılmıştır. Paremetrik veriler için One-way ANOVA varyans analizi kullanılmıştır. $\mathrm{P}<0,05$ istatistik olarak anlamlı kabul edilmiştir.
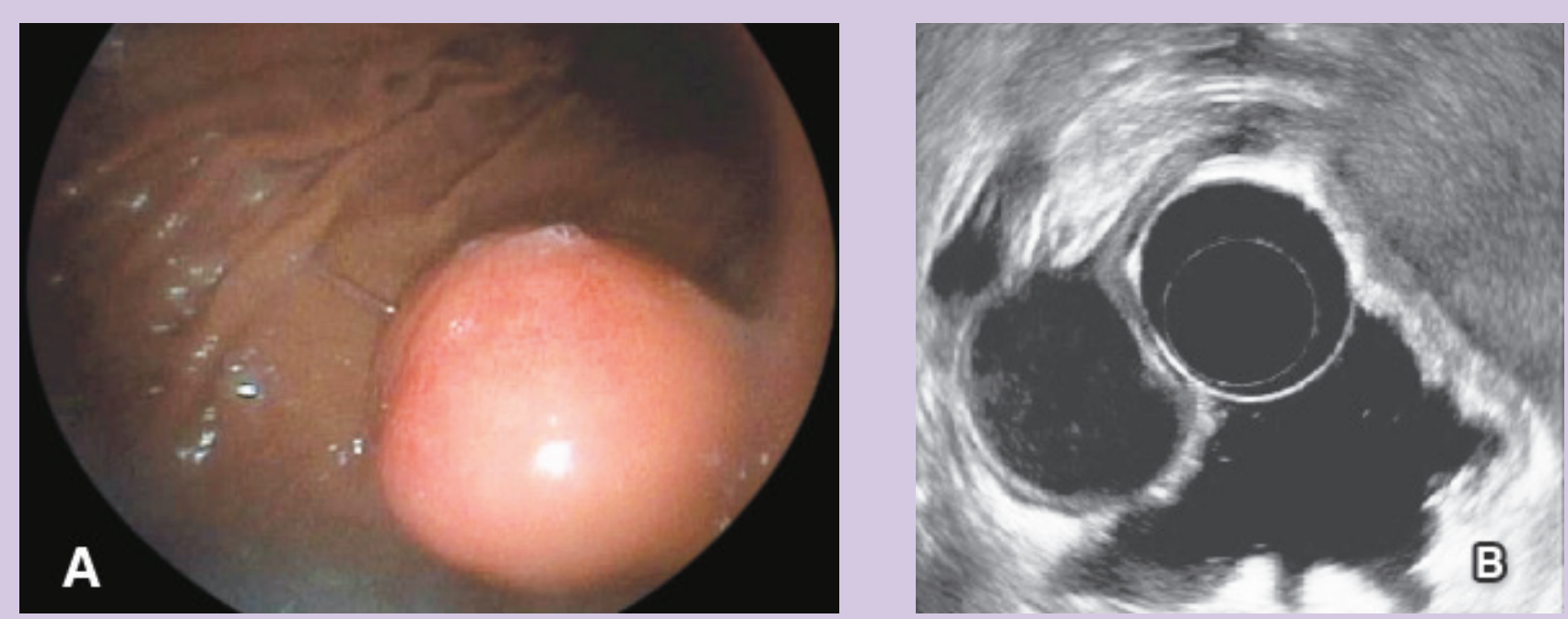

Resim 1. Midede submukozal lezyonun endoskopik görüntüsü (A). Midedeki submukozal lezyonun EUS görüntüsü, lezyon mide muscularis propria tabakası ile bağlantııdır ve düzgün konturludur (B). 


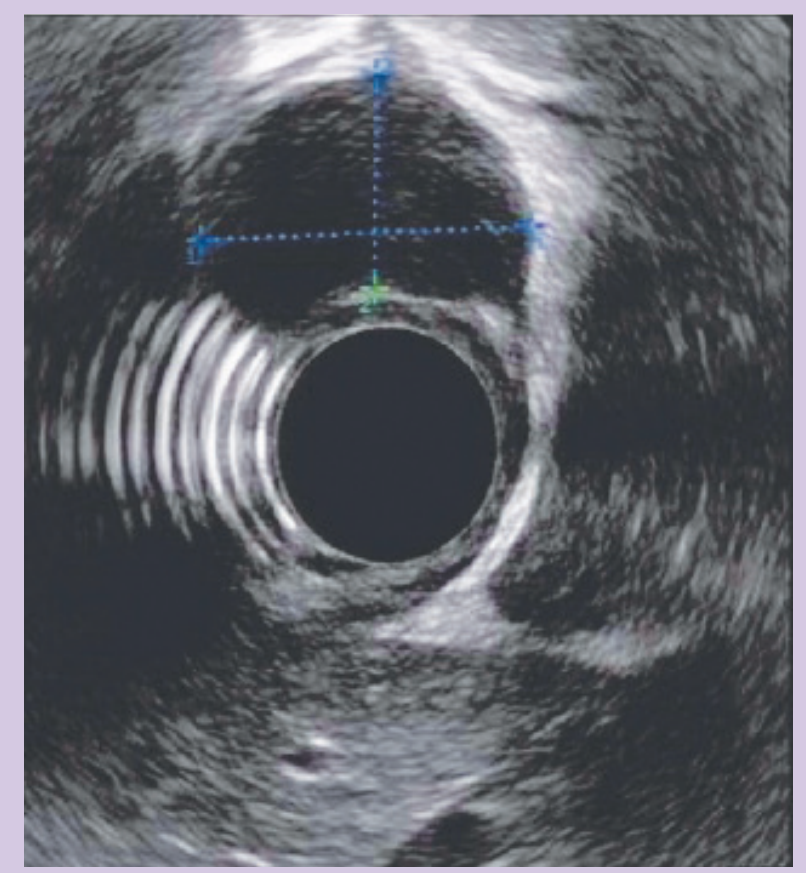

Resim 2. Özofagus distalde mezenkimal lezyon. Bulgular leimyom ile uyumludur.

\section{BULGULAR}

Çalışmaya yaş ortalaması 52.6+12.1 yıl (30-84 yaş aralığında) olan 18 erkek, 9 bayan dahil edilmiştir. Lezyonların 13'ü midede, 14'ü özofagusta yer almaktadır ve ortalama çap 29.5
土15.6 (7-57 mm) ölçülmüştür (Resim 1 A-B, 2). Lezyonların mide tabakaları ile ilişkisi, ekojenik özellikleri, kontur düzensizlikleri kaydedilmiştir. (Resim 3 A ve B).

Olgulara 19 veya 22 G iğne kullanılarak EUF-FNA uygulanmiş ve tamamında aspirasyon örneği elde edilmiştir (Resim 4, 5 A-B). Alınan örnekler sitopatolojik yayma yapılarak ve thin prep solüsyonunda patoloji laboratuvarına gönderilmiştir. Kitle lezyonlara uygulanan toplam 27 EUS-FNA materyalinin sitopatolojik incelemesinde 14'ünde (\%51.8) iğsi hücreler görülmüştür. Bunlardan 2 olguda malign davranışlı GIST tanısına ulaşılmış, 4 olguda mezenkimal tümor açısından kuşkulu sitoloji bildirilmiş, kalan 8 olguda iğsi hücre toplulukları görülmüştür (Resim 6 A-B). Dokuz olguda hazırlanan hücre bloklarına IHC ile CD117 boyası uygulanmış ve biri malign GIST ve birisi kuşkulu sitoloji bildirilen iki olguda pozitiflik bildirilmiştir. Malign GIST tanısına ulaşılan olgularda midede mezenkimal kitle ve perigastrik lenf nodu metastazı saptanarak her iki lezyona EUS-FNA uygulanmıs, lenf nodlarından alınan materyalle birlikte malign, metastatik GIST tanısına ulaşılmıştır (Resim 7 A-B). Onüç olguda EUS-FNA materyali nondiagnostik olarak rapor edilmiştir. Üç olguya bu nedenle ikinci biyopsi uygulanmış ve iki olguda iğsi hücreler görülerek GIST tanısına ulaşılmıştır. Bu olgularla birlikte tanı oranı \%59.25'e ulaşmıştır.

Lezyon büyüklüklerine göre tanı oranlarına bakıldığında lezyonlar 2 cm'den küçük, 2 cm ve üstü olarak iki gruba ayrılmıştır. Toplam 10 lezyonun en büyük çapı $2 \mathrm{~cm}$ altında olup
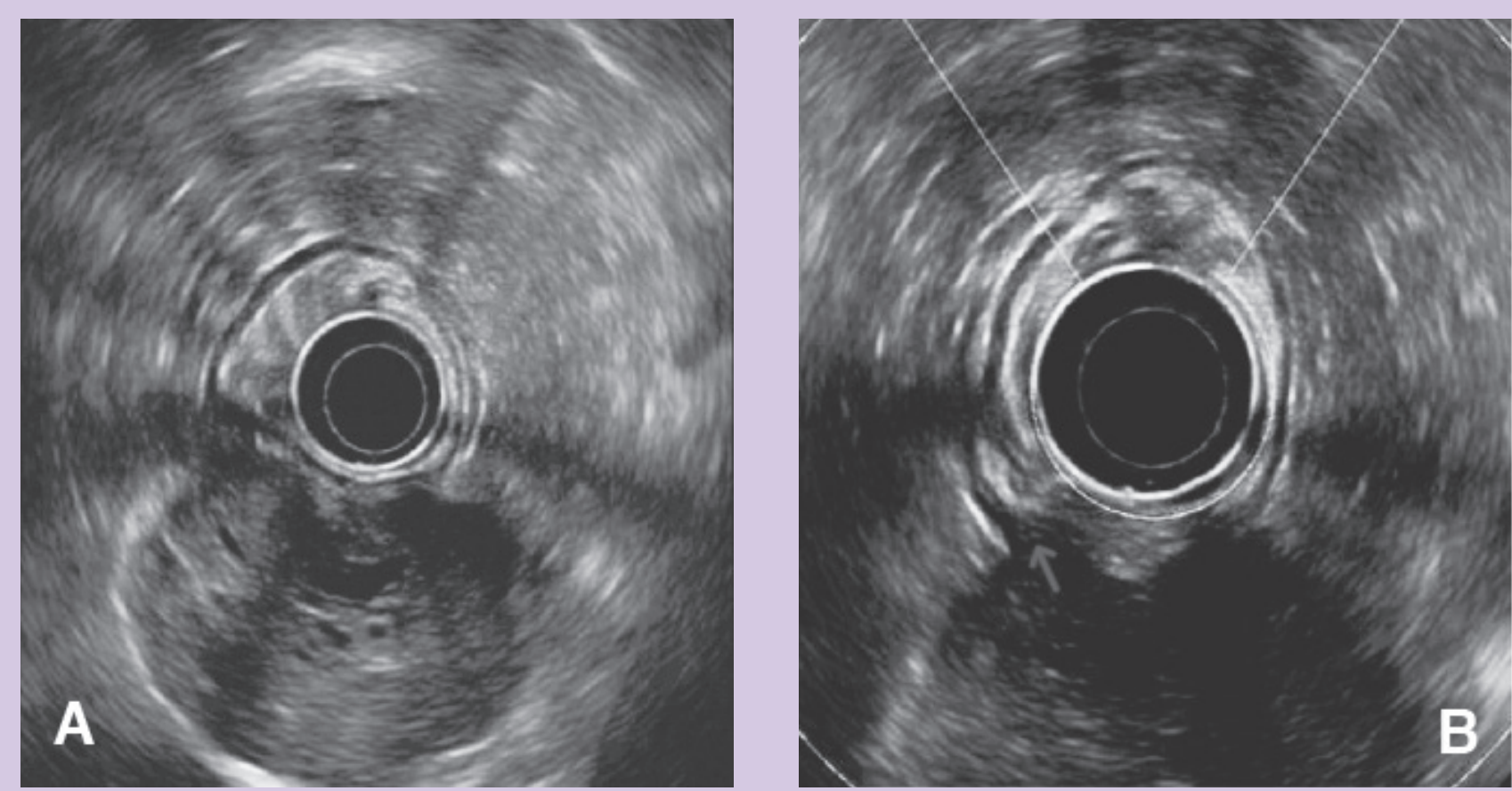

Resim 3. Midede GIST ile uyumlu mezenkimal lezyon. Bu alanda 55x46 mm boyutlarında, submukozal yerleşimli, lobule konturlu, homojen hipoekoik içerisinde anekoik alanlar bulunan tümöral kitle izlenmektedir (A). Kitle midenin muscularis propria tabakası ile bağlantılıdır (B). 


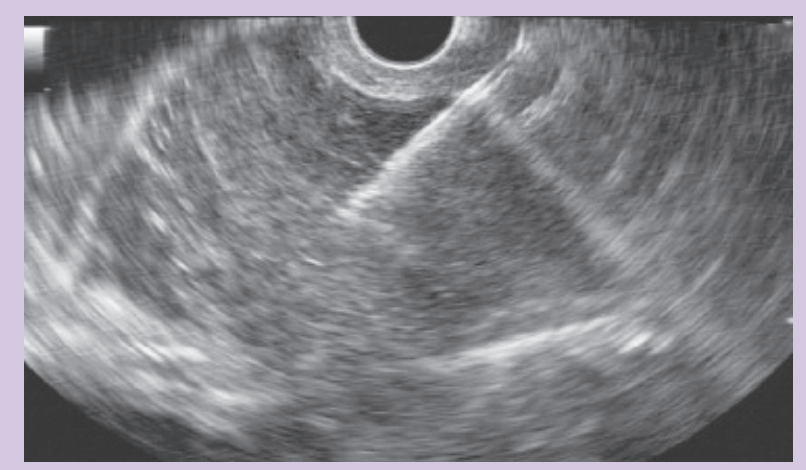

Resim 4. Distal özofagustaki mezenkimal lezyona EUS-FNA uygulaması. bunlardan üç olguda iğsi hücreler görülerek tanıya ulaşılmış ve EUS-FNA tanı oranı \%30 bulunmuştur. En büyük çapı 2 $\mathrm{cm}$ ve üzeri olan toplam 17 lezyondan alınan EUS-FNA tanı oranı ise \%64.7 olarak saptanmıştır.

EUS-FNA işlemleri 19 G veya 22 G iğne kullanılarak yapılmıştır. Lezyonlarda 19 ve $22 \mathrm{G}$ ile alınan örneklerde tanı oranları arasında fark saptanmamıştır. Işslemler sırasında veya sonrasında herhangi bir komplikasyon izlenmemiştir.

\section{TARTIŞMA}

Endoskopik incelemeler sırasinda saptanan submukozal lezyonların ayırıcı tanisında EUS incelemesi altın standart hale
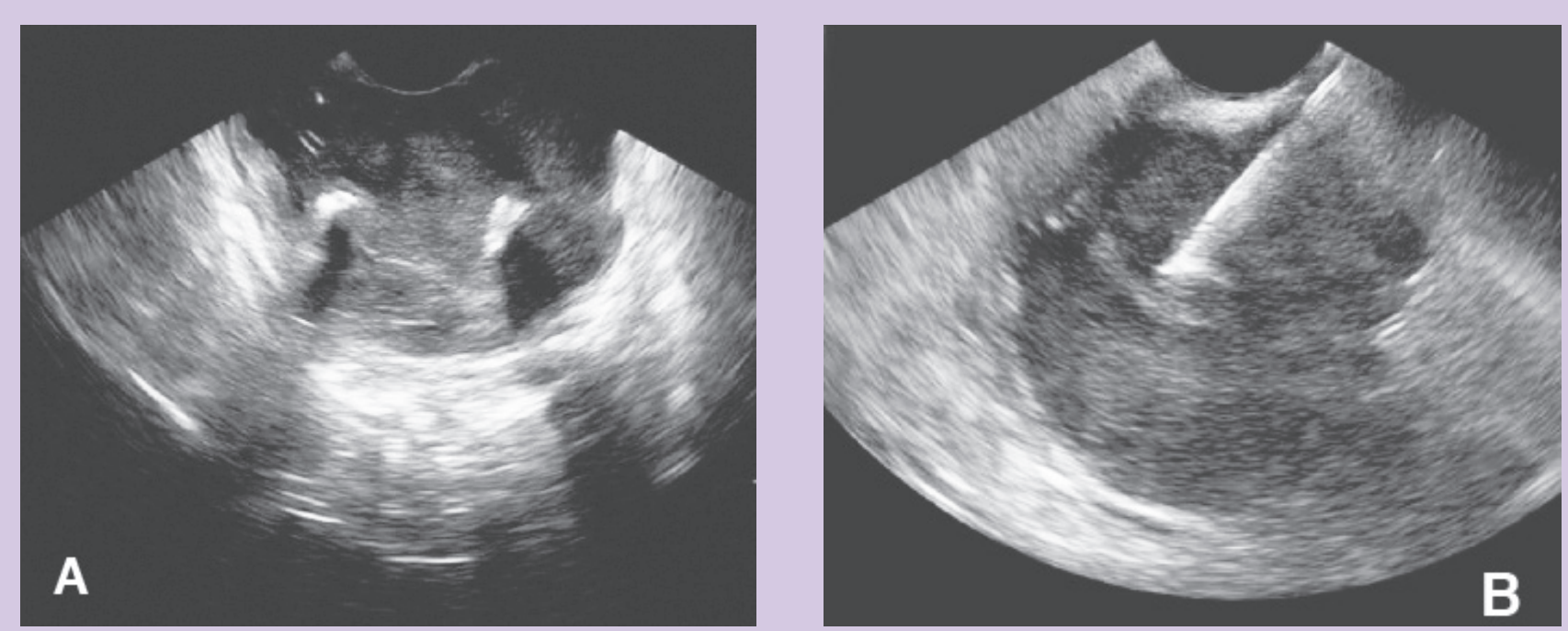

Resim 5. Kardio-özofageal bileşkede lobüle, heterojen, içerisinde küçük anekoik ve hiperekojen odaklar içeren genel olarak hipoekoik tümoral kitle izlendi. Bazı kesitlerde kitlenin muscularis propria tabakası ile bağlantılı olduğu düşünüldü (A). Kitleye 22 G iğne ile ile EUS-FNA uygulandı (B).
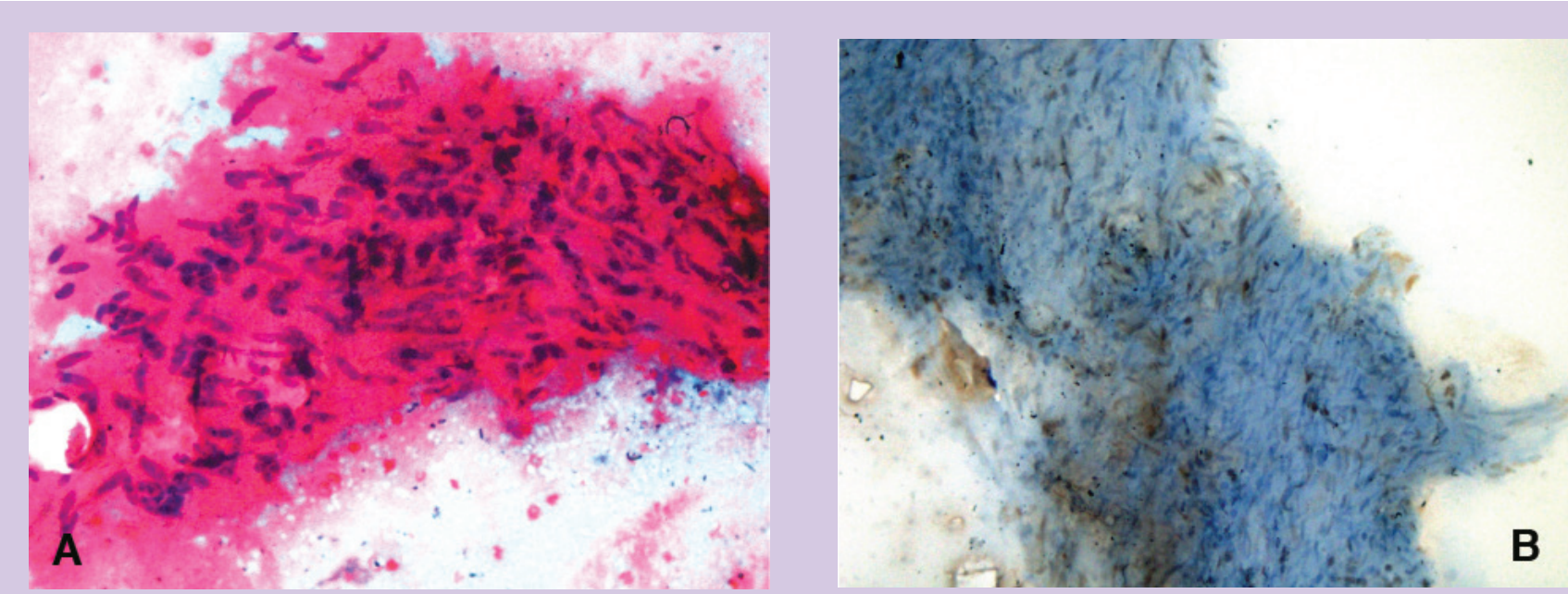

Resim 6. Midede yerleşmiş GIST olgusunun EUS-FNA materyalinden hazırlanan hücre bloğunda iğsi hücrelerin varlığı (A) ve fokal Cd117 pozitifliği (B) izleniyor. 


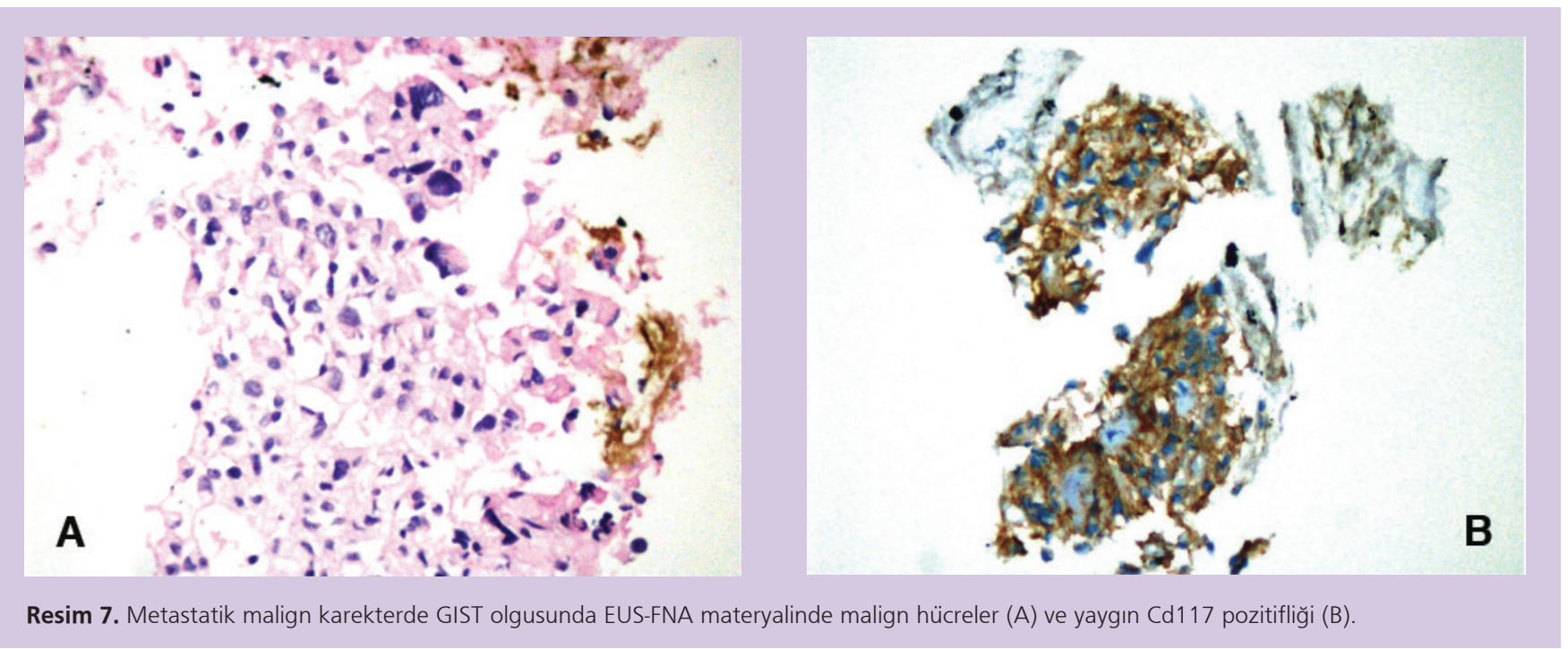

gelmiştir. EUS lezyonun değerlendirilmesini ve aynı zamanda lezyonlardan FNA ile örnek alınmasını sağlamaktadır. Submukozal lezyonlarda endoskopik biyopsiler tanı sağlamazken EUS-FNA ile alınan örneklerin tanıya katkı sağlayabileceği düşünülmektedir.

Subepitelyal lezyonlarda ayırıcı tanı yapılması takip ve tedavi kararını etkilemektedir. Benign olduğu düşünülen leimyom gibi subepitelyal lezyonlarda biyopsi veya cerrahi gerekmeyebilmektedir. Buna karşın GIST'lerin tümünde malignite riski bulunduğu kabul edilmektedir (7). GIST olgularının tanısinda kullanılan EUS tümörün malign potansiyeli hakkında bilgiler verebilmektedir. Chak ve arkadaşları endosonografik olarak GIST'lerin çapının 4 cm'den büyük olmasını, hiperekoik alanların varlığını, lezyonun şekil veya sınır düzensizliğini malignite potansiyelini gösteren bulgular olarak yorumlamışlardır (8). Bu özelliklerin birkaçının bir arada olması durumunda EUS \%100'e yakın duyarlılıkla malign lezyonları saptayabilmektedir (9). Daha önce yaptığımız çalışmada üst gastrointestinal sistemdeki GIST'lerin EUS incelemesinde tümör çapının 50 mm'nin üzerinde olması, ekstralüminal yüzeyde kenar düzensizliğinin bulunması, ve tümörlerin anekoik ve hiperekoik alanlar içeren heterojen eko yapıda olmasının malignite açısından yüksek riskli olduğunu gösterdiğini saptamıştık (4). Bu çalışmada benzer şekilde malign GIST olarak bildirilen iki olguda tümör çapı 5 cm'den büyüktür ve kenar düzensizliği mevcuttur. Bu hastalarda ayrıca patolojik lenf nodları saptanmıştır. Her iki olguda tümöral lezyona ve eşlik eden patolojik lenf nodlarına FNA uygulanmış ve EUS-FNA ile malign GIST tanısına ulaşılmıştır.

Üst gastrointestinel sistemde yerleşmiş mezenkimal lezyonlarda EUS-FNA'nın etkinliği konusu tartışmalıdır. Ilk yayınlar bu lezyonlarda EUS- FNA ile yüksek oranda sitopatolojik tanı sağlanabileceğini göstermiştir $(10,11)$. Buna karşın Hoda ve ark. çalışmasında ortalama çapı 28 mm olan gastrik submukozal lezyonlara 22 G iğne ile EUS-FNA uygulamış ve \%62 tanı oranı elde etmişlerdir (12). Hoda ve ark. çalışmasında EUS-FNA ile 10 mm'den küçük submukozal lezyonlarda tanı oranı \%40-50, 10-30 mm arasındaki lezyonlarda tanı oranı \%60-70 olarak saptanmıştır (12). Stelow ve ark. çalışmalarinda EUS ve EUS-FNA ile submukozal lezyonlara konan tanıları, cerrahi uygulanan hastalardaki patolojik kesin tanıyla karşılaştırmışlar ve \%93 oranında doğru tanı konduğunu göstermişlerdir (13). Buna karşın EUS-FNA ile tanı konmaya yeterli materyal elde edebilme oranı \%40-70 oranlarında kalmaktadır (13). Assef ve ark. çalışmalarında submukozal lezyonlarda EUS-FNA sonuçlarını incelemişler ve tanı oranı ile lezyon çapı arasındaki bağlantıları araştırmışlardır. Küçük lezyonlara EUS-FNA uygulandığında tanı başarı oranları \%58.7 kadar düşmekte, 3 cm'den büyük lezyonlarda bu oran \% 80'lere kadar çıkabilmektedir $(14,15)$. Bizim çalışmamızda submukozal lezyonların çapı 17 olguda $2 \mathrm{~cm}$ üzerinde olup bu vakalarda EUS-FNA başarı oranı \%64.7 olarak saptanmıştır. Çalışmamızda ortalama tümör çapı yaklaşık $3 \mathrm{~cm}$ olup lezyonların küçük olmasının EUS-FNA başarı oranını azaltan bir neden olabileceği düşünülmüştür. Büyük lezyonlarda tanı başarı oranı artmakta ve lezyonun malign potansiyeli doğru tahmin edilebilmektedir. Ancak büyük mezenkimal lezyonların malign potansiyelinin daha yüksek olduğu ve bu lezyonlara biopsi yapılmadan cerrahi önerilebileceği bir gerçektir. Küçük mezenkimal lezyonların ayırıcı tanısının yapılması tanı, tedavi ve takip kararını etkileyeceği için önemlidir. Buna karşın küçük lezyonlarda EUS-FNA başarı oranı daha düşük izlenmektedir (16).

Mezenkimal lezyonlarda EUS-FNA sırasında ne kadar fazla histopatolojik örnek alınabilirse tanı oranının o kadar yüksek olacağı bildirilmiştir. Bu amaçla mezenkimal lezyonların tanısında EUS eşliğinde trukut biopsi ile FNA etkinliğini 
karşlaştıran çalışmalar mevcuttur. $\mathrm{Na}$ ve ark. çalışmasında mezenkimal lezyonlarda EUS ile trukut biopsinin tanısal duyarlılığını FNA'dan daha yüksek saptamıştır (77.8\% karşın. 38.7\%). Ancak trukut biopsi komplikasyon oranları yüksek olduğu için artık EUS pratiğinde nadiren kullanılmaktadır. Na ve ark. çalışmasında FNA ile GIST tanısına \%68.8 vakada ulaşmıştır. GIST dışı subepitelyal lezyonlarda EUS-FNA ile tanı konma oranı \%14.3'e kadar düşmüştür (17). GIST için uygulanan EUS-FNA'larda hastanın yaşı ve lezyonun midenin distal kısmında yer alması FNA başarısını olumsuz etkilemektedir (18). Mezenkimal lezyonlarda kor biopsi alınması başarı oranlarını artırabilmektedir. Ancak iğne çapı arttıkça EUS işlemi sırasında teknik zorluklar artmaktadır (19). Bizim çalışmamızda trukut biyopsi uygulanmamıştır. FNA işlemlerinde kullanılan iğne çapı ile başarı oranları orasında ise anlamlı bir fark bulunmamıştır. Çalışmamızın eksikliklerinden biri vakalarda kesin patolojik tanıya ulaşılmamış olmasıdır. Ancak çalışmanın amacı EUS-FNA ile elde edilen materyalin yeterliliğin incelenmesidir. Ayrıca onsite patoloğun bulunmaması çalışmanın sonuçlarını etkileyen bir faktördür. Onsite patolojik inceleme işlem sırasında EUS-FNA pass sayısı artırılarak tanı başarısını artırabilmektedir. Biz ilk biyopside tanıya ulaşılamayan üç vakada tekrar FNA uyguladığımızda iki olguda tanı sağlanmıştır.

Üst gastrointestinal sistemdeki mezenkimal lezyonlara EUSFNA yapılması konusunda bir fikir birliği yoktur. Almanya'da yakın zamanda yapılan çok merkezli çalışma üst GIS mezenkimal lezyonlara yaklaşım konusunda farklı görüşler olabileceğini ortaya koymuştur. Yapılan anket çalışmasında 42 farklı EUS merkezinin submukozal lezyonlara yaklaşımı irdelenmiştir. EUS ile ilgilenenlerin \%97'i GIST tanısını doğru koyabilmek için en iyi yolun doku tanısı olduğu cevabını verirken, EUS yapan doktorların sadece \%18'i böyle vakalara rutin EUS-FNA yaptığını rapor etmiştir. Ankete katılan hekimlerin \%68'i ise üst GIS subepitelyal lezyonlarda bazen EUS FNA yapmaya gerek duydugunu \%11 hekim ise bu lezyonlara FNA yapmadığını bildirmiştir. GIST için mide duvarının dördüncü tabakasından köken almak, hipoekoik görünüm ve lokasyon, GIST tanısını tahmin etmede gerekli görülürken CD117 negatif bile olsa EUS özellikleri yeterli ise ve iğsi hücre görülmüşse GIST tanısı konabileceği görüşü bildirilmiştir. Bu nedenle ankete katılan hekimlerin \%55'i GIST tanısında EUS-FNA'nın \%50'den az katkı sağlayacağını düşündügünü söylemiştir. Bu çalışma hekimlerin mezenkimal lezyonlara EUS yaklaşımlarının farklı olabileceğini göstermektedir (20). Bu durum ülkemiz için de geçerli olup, ülkemizde EUS-FNA yapan merkezlerin çok az olduğu da göz önüne alındığında çoğu olguya EUS-FNA uygulanmadığı görülmektedir (4).

Gastrointestinal mezenkimal tümörlerde EUS-FNA tanıı \%51.8 olguda destekler bulgular vermiş, iki olguda malign GIST tanısına ulaşılmıştır. Tekrarlayan EUS-FNA ile tanı oranı \%59.25'e ulaşmıştır. Ancak olguların önemli bir kısmı opere edilmediği için EUS-FNA uygulamasının mezenkimal tümörlerdeki duyarlılığını hesaplamak mümkün olmamıştır. Kliniğimizde onsite patoloğun bulunmaması ve biyopsi uygulanan lezyonların çapının küçük olması başarı oranının düşük olmasında önemli bir faktör olabilir. Sonuç olarak EUS mezenkimal lezyonların tanısında tedavi öncesi uygulanması gereken bir yöntemdir. EUS-FNA'nın tanıya katkısı düşük olmakla birlikte seçilmiş vakalarda güvenle uygulanabilir.

\section{KAYNAKLAR}

1. Pidhorecky I, Cheney RT, Kraybill WG, Gibbs JF. Gastrointestinal stromal tumors: current diagnosis, biologic behavior, and management. Ann Surg Oncol 2000; 7:705-12

2. Okai T, Minamoto T, Ohtsubo K, et al. Endosonographic evaluation of c-kit-positive gastrointestinal stromal tumor. Abdom Imag 2003;28:3017 .

3. Shah P, Gao F, Edmundowicz SA, Azar RR, Early DS. Predicting malignant potential of gastrointestinal stromal tumors using endoscopic ultrasound. Dig Dis Sci 2009;54:1265-9.

4. Oruc N, Aydın A, Tekin F, et al. Üst gastrointestinal sistem stromal tümörlerinin endosonografik ve histopatolojik özelliklerinin karşılaştırılması: Tek merkez deneyimi. Endoskopi 2009;17:06-11.

5. Matsui M, Goto H, Niwa Y, et al. Preliminary results of fine needle aspiration biopsy histology in upper gastrointestinal submucosal tumors. Endoscopy 1998;30:750-5.

6. Ito $\mathrm{H}$, Inoue $\mathrm{H}$, Ryozawa $\mathrm{S}$, et al. Fine-needle aspiration biopsy and endoscopic ultrasound for pretreatment pathological diagnosis of gastric gastrointestinal stromal tumors. Gastroenterol Res Pract 2012;2012:139083.

7. DeMatteo RP, Lewis JJ, Leung D, et al. Two hundred gastrointestinal stromal tumors: recurrence patterns and prognostic factors for survival. Ann Surg 2000;231:51-8.

8. Chak A, Canto MI, Rosch T, et al. Endosonographic differentiation of benign and malignant stromal cell tumors. Gastrointest Endosc $1997 ; 45: 468-73$

9. Palazzo L, Land B, Cellier C, et al. Endosonographic features predictive of benign and malignant gastrointestinal stromal tumours. Gut 2000;46:88-92.

10. Chatzipantelis P, Salla C, Karoumpalis I, et al. Endoscopic ultrasound-guided fine needle aspiration biopsy in the diagnosis of gastrointestinal stromal tumors of the stomach. A study of 17 cases. J Gastrointestin Liver Dis 2008;17:15-20.

11. Ando N, Goto H, Niwa Y, et al. The diagnosis of GI stromal tumors with EUS-guided fine needle aspiration with immunohistochemical analysis. Gastrointest Endosc 2002;55:37-43.

12. Hoda KM, Rodriguez SA, Faigel DO. EUS-guided sampling of suspected GI stromal tumors. Gastrointest Endosc 2009;69:1218-23.

13. Stelow EB, Murad FM, Debol SM, et al. A limited immunocytochemical panel for the distinction of subepithelial gastrointestinal mesenchymal neoplasms sampled by endoscopic ultrasound-guided fine-needle aspiration. Am J Clin Pathol 2008;129:219-25.

14. Akahoshi K, Oya M, Koga T, et al. Clinical usefulness of endoscopic ultrasound-guided fine needle aspiration for gastric subepithelial lesions smaller than 2 cm. J Gastrointestin Liver Dis 2014;23:405-12. 
15. Assef M, Rossini L, Neto GS, et al. Influence of layer, size and organ of subepithelial lesions of upper gastrointestinal tract in outcomes of endoscopic ultrasound-guided fine-needle aspiration. Endosc Ultrasound 2014;3(Suppl 1):S16.

16. Franco MC, Schulz RT, Maluf-Filho F. Opinion: How to manage subepithelial lesions of the upper gastrointestinal tract? World J Gastrointest Endosc 2015;7:1262-7.

17. Na HK, Lee JH, Park YS, et al. Yields and utility of endoscopic ultrasonography-guided 19-Gauge trucut biopsy versus 22-Gauge fine needle aspiration for diagnosing gastric subepithelial tumors. Clin Endosc 2015:48:152-7.
18. Suzuki T, Arai M, Matsumura T, et al. Factors associated with inadequate tissue yield in EUS-FNA for gastric SMT. ISRN Gastroenterol 2011;2011:619128.

19. Fernández-Esparrach G, Sendino O, Solé M, et al. Endoscopic ultrasound-guided fine-needle aspiration and trucut biopsy in the diagnosis of gastric stromal tumors: a randomized crossover study. Endoscopy 2010;42:292-9.

20. Jenssen C, Barreiros AP, Will U, et al. German survey on EUS-guided diagnosis and management of gastrointestinal stromal tumors (GISTs) evidence or "gut-feeling"? Ultraschall Med 2015;36:494-500. 